\title{
Tegenaria hasperi Chyzer, 1897 and Zoropsis spinimana (Dufour, 1820), newly recorded synanthropic spiders from Slovakia (Araneae, Agelenidae, Zoropsidae)
}

\author{
Pavol Purgat ${ }^{1,2^{*}}$, Natália Ondrejková ${ }^{2}$ Zuzana Krumpálová ${ }^{2}$, Peter Gajdoš ${ }^{1}$, Natália Hurajtová ${ }^{1,2}$ \\ 1 Institute of Landscape Ecology, Slovak Academy of Sciences, Nitra, Slovakia •PP: pavol.purgat@ukf.sk https://orcid.org/0000-0002-1504- \\ 7659•PG: nrukgajd@savba.sk (1) https://orcid.org/0000-0003-2055-461X•NH: n.hurajtova@savba.sk (1) https://orcid.org/0000-0002-9296- \\ 4944 \\ 2 Faculty of Natural Sciences, Constantine the Philosopher University in Nitra, Nitra, Slovakia • NO: natalia.ondrejkova@ukf.sk•ZK: zkrumpalova \\ @ukf.sk (D https://orcid.org/0000-0003-2246-6533 \\ * Corresponding author
}

\begin{abstract}
Tegenaria hasperi Chyzer, 1897 (Agelenidae) and Zoropsis spinimana (Dufour, 1820) (Zoropsidae) are recorded in Slovakia for the first time. Both species were collected in synanthropic habitats in Western Slovakia. Two males of $T$. hasperi were collected in the garden of a family house, and both sexes of $Z$. spinimana were recorded from the interiors and exteriors of buildings in four separate cities, representing the first record of the family Zoropsidae in Slovakia. This contribution provides additional information on the morphological characteristics of these species. Digital images of their habitus and copulatory organs, as well as their distribution and habitat preferences are included.
\end{abstract}

\section{Keywords}

Central Europe, distribution, faunistics, first records, introduced, non-native species

Academic editor: Alireza Zamani | Received 4 January 2021 | Accepted 20 April 2021 | Published 17 May 2021

Citation: Purgat P, Ondrejková N, Krumpálová Z, Gajdoš P, Hurajtová N (2021) Tegenaria hasperi Chyzer, 1897 and Zoropsis spinimana (Dufour, 1820), newly recorded synanthropic spiders from Slovakia (Araneae, Agelenidae, Zoropsidae). Check List 17 (3): $775-782$. https://doi.org/10.15 $660 / 17.3 .775$

\section{Introduction}

Research into synanthropic spider species in the territory of Slovakia has a relatively long history, starting in earnest in the mid 1980s with published reports of several synanthropic species new for the Slovak fauna, including: Oonops domesticus Dalmas, 1916 (Žitňanská 1975), Cheiracanthium mildei L. Koch, 1864 (Bílek 1975), Spermophora senoculata (Dugès, 1836), and Triaeris stenaspis (Simon, 1892) (Miller and Žitňanská 1976). The results of this research were summarized by Szinetár et al. (2020). In the last decade, in addition to alien eusynanthropic species new for the Slovak fauna (e.g., Parasteatoda tabulata (Levi, 1980) (Šestáková and Gajdoš 2011), Coleosoma floridanum Banks 1900 (Šestáková et al. 2013), Scytodes fusca Walckenaer, 1837 (Šestáková et al. 2014), and Hasarius adansoni (Audouin, 1826) (Šestáková et al. 2017)), species native to the continent have been found in Slovakia. These are species that have spread from other parts of Europe into Slovakia (e.g., 
Uloborus plumipes Lucas, 1846 in a botanical garden in Košice; Suvák 2013). Our paper includes two more species of native European spiders, classified by Szinetár et al. (2020) as synanthropic in the conditions of Central Europe (Hungary, Slovakia, and Romania): the moderately typical hemisynanthropic Tegenaria hasperi Chyzer, 1897 (Agelenidae) and the eusynanthropic Zoropsis spinimana (Dufour, 1820) (Zoropsidae).

\section{Methods}

All of the studied material were collected/photographed in Western Slovakia (Figs 1, 3). Specimens of Tegenaria hasperi were collected in the village of Machulince using pitfall traps installed in wood storage and an orchard near a family house from October 2017 to October 2018. Three individuals of Zoropsis spinimana were collected by direct sampling in buildings in the cities of Nitra and Sered'; three other individuals were observed and photographed in the cities of Bratislava and Pezinok.

Microscopic images of the habitus and copulatory organs and measurements were obtained using an Olympus SC 100 attached to an Olympus SZx16 stereomicroscope and edited with Olympus Stream basic. Images were taken in different focal planes, and stack images were combined using Zerene Stacker. All measurements are in millimeters. The preserved specimens are deposited in the Institute of Landscape Ecology of the Slovak Academy of Sciences, Nitra (ILE SAS, curator: P. Purgat).

\section{Results}

Agelenidae C.L. Koch, 1837

\section{Tegenaria hasperi Chyzer, 1897}

Figure 2

Identification references. Deltshev 1993: 172, figs 14, 15 (ð)); Seyyar et al. 2009: 122-124, figs 2, 3 (ð)). For the complete list of references, see World Spider Cata$\log (2021)$.

Material examined. SLOVAKIA - Western Slovakia

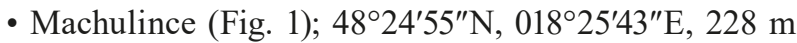
a.s.1.; 1.VI-VII.2018; N. Ondrejková, Z. Krumpálová

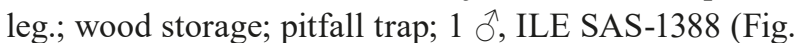
2A) - Machulince; 48 $24^{\prime} 52^{\prime \prime} \mathrm{N}, 018^{\circ} 25^{\prime} 40^{\prime \prime} \mathrm{E}, 227 \mathrm{~m}$ a.s.l.; 1.VI-1.VII.2018; N. Ondrejková, Z. Krumpálová

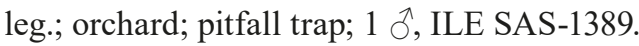

Identification. Male pedipalp: tibial apophysis formed by two strongly chitinized protrusions separated by a

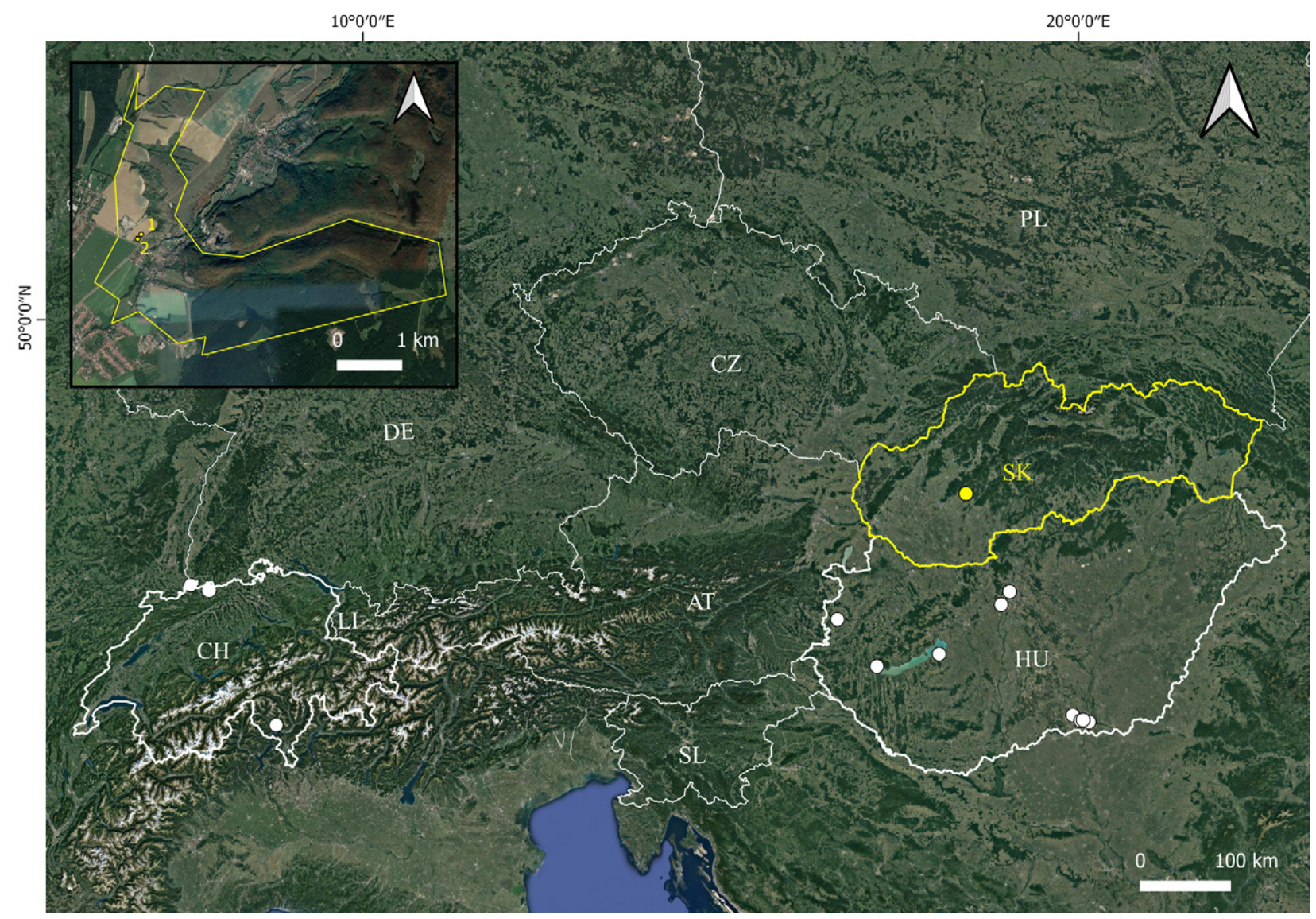

Figure 1. Distribution of Tegenaria hasperi in Central Europe (Ištok 1999); white border = borders of Central European countries, yellow border $=$ Slovak border, white circle $=$ published records updated according to the literature (Hänggi et al. 2014; Hänggi and Straub 2016; Szinetár and Vajda 1992; Kovács and Szinetár 2012), yellow circle $=$ new records, $1=$ locality Machulince, wood storage, $2=$ locality Machulince, orchard; AT - Austria, CZ - Czech Republic, DE - Germany, HU - Hungary, CH - Switzerland, LI - Liechtenstein, SK - Slovakia, SL - Slovenia, PL - Poland. 
A
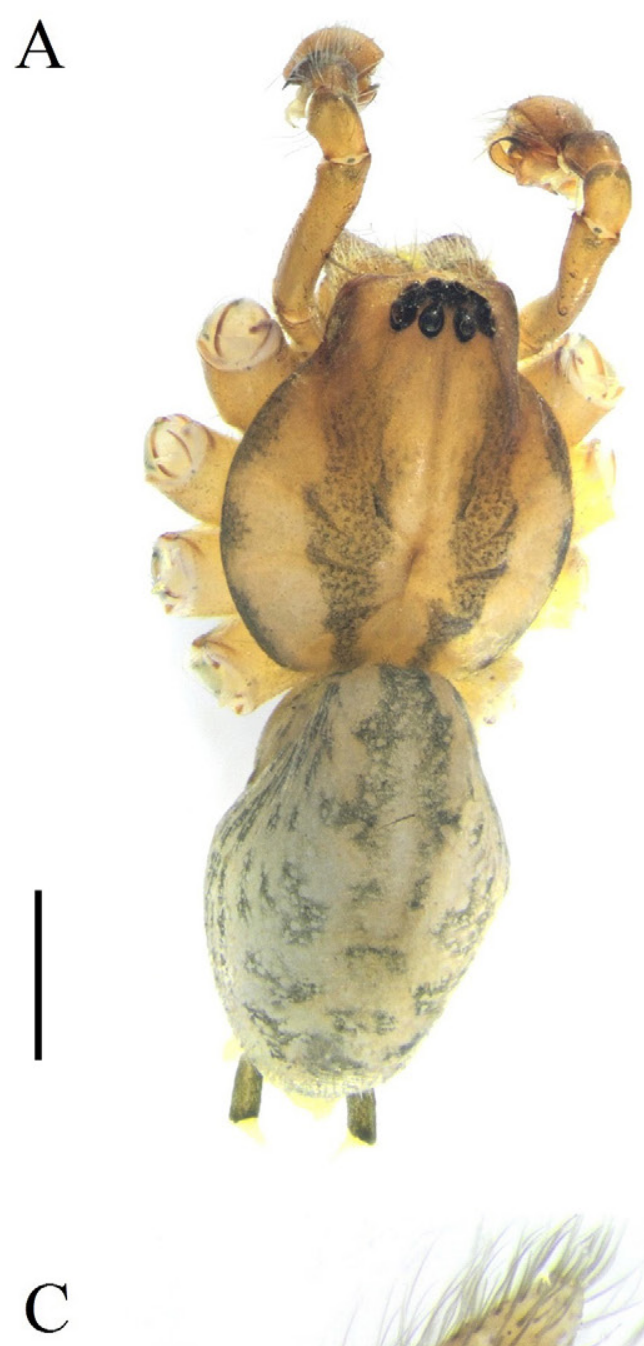

$\mathrm{C}$

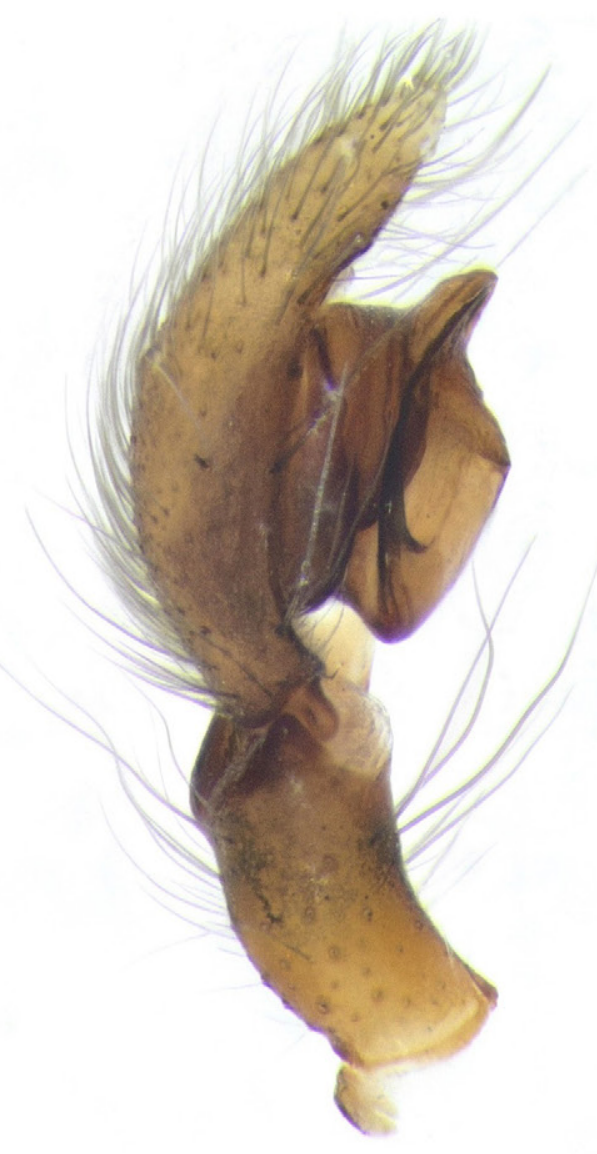

B

$\mathrm{D}$

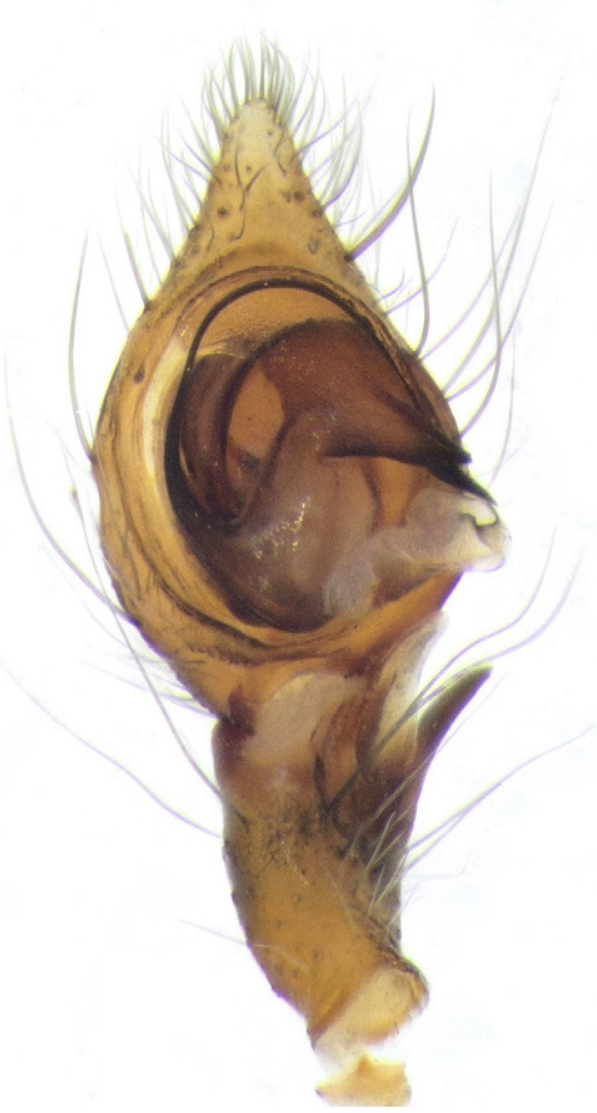

Figure 2. Tegenaria hasperi Chyzer, 1897 from Slovakia. A. Adult male. B. Left pedipalp, dorsoretrolateral view. C. Idem., prolateral view. D. Idem., ventral view. Scale bars: $A=1 \mathrm{~mm}, B-D=0.2 \mathrm{~mm}$ 


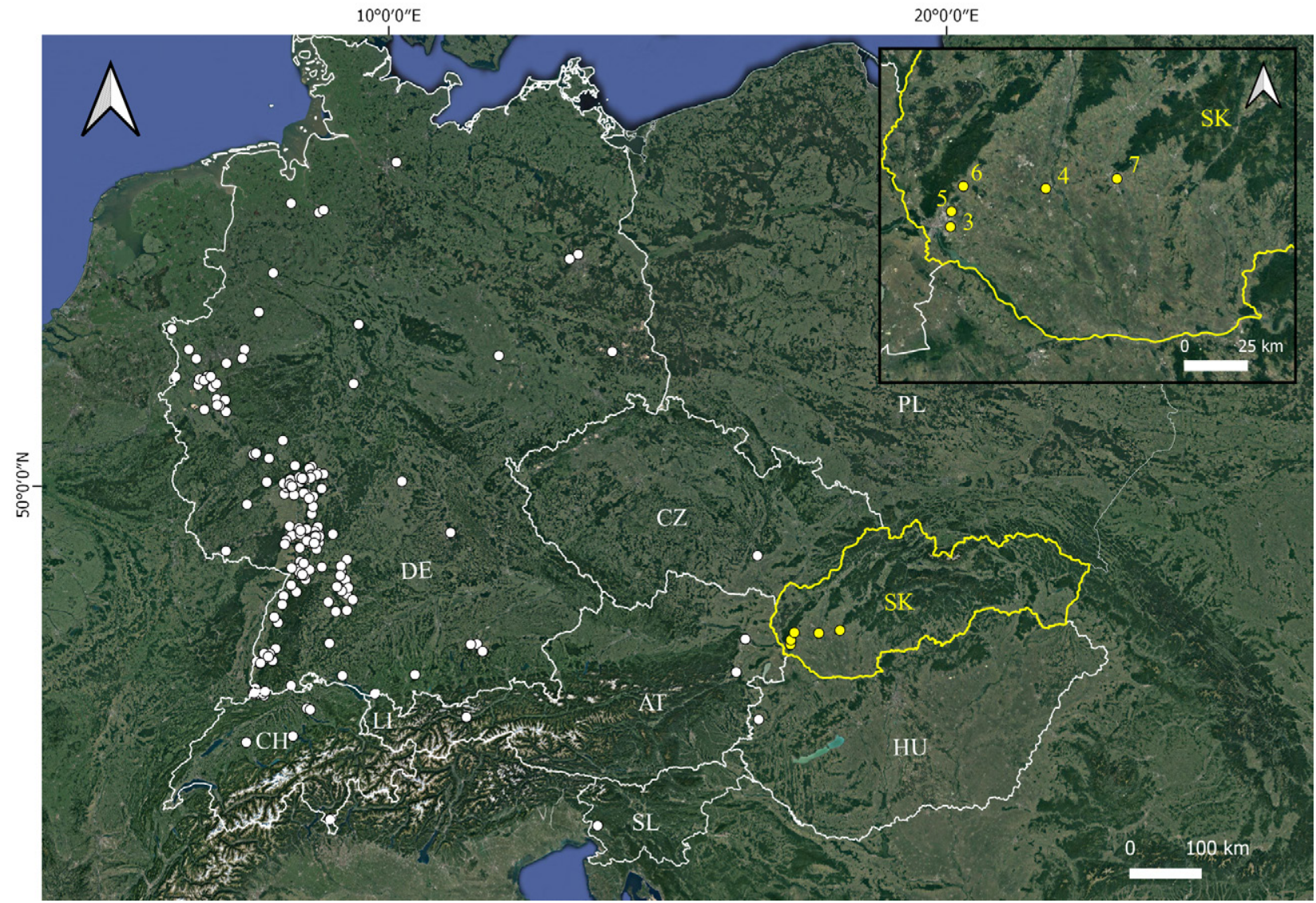

Figure 3. Distribution of Zoropsis spinimana in Central Europe (lštok 1999); white border = borders of Central European countries, yellow border $=$ Slovak border, white circle $=$ published records updated according to the literature (Thaler and Knoflach 1998; Kuntner and Kostanjšek 2000; Kostanjšek and Kuntner 2002; Hänggi 2003; Hänggi and Bolzern 2006; Szinetár et al. 2014; Dolejš and Prudek 2019; Atlas of the European Arachnids 2021), yellow circle = new records, $3=$ locality Bratislava, Vrakuňa, $4=$ locality Sered', $5=$ locality Bratislava, Vajnory, 6 = locality Pezinok, 7 = locality Nitra; AT - Austria, CZ - Czech Republic , DE - Germany, HU - Hungary, CH - Switzerland, LI Liechtenstein, SK - Slovakia, SL - Slovenia PL - Poland.

narrow gap; spoon-shaped protrusion above tibial apophysis, adjacent to the lower part of the bulb (Fig. 2B); embolus consists of two protrusions, the lower being longer and more pointed (Fig. 2B-D) (Kovács and Szinetár 2012). Female epigyne: distinct rectangular median plate (Nentwig et al. 2020).

Measurements of the two Slovak males (Fig. 2). Body length: 4.34 and 4.99; prosoma length: 2.25 and 2.38, width 1.98 and 2.21; opisthosoma length: 2.09 and 2.61, width 1.26 and 1.75 .

\section{Zoropsidae Bertkau, 1882}

\section{Zoropsis spinimana (Dufour, 1820)}

Figures 4-7

Identification references. Thaler and Knoflach 1998: 175-176, figs 2-6 (ठ, o $)$ ); Griswold and Ubick 2001: 112, figs $2-5(\hat{0},+9)$. For the complete list of references, see World Spider Catalog (2021).

Material examined. SLOVAKIA - Western Slovakia - Sered' (Fig. 3); 48 $16^{\prime} 39^{\prime \prime} \mathrm{N}, 017^{\circ} 42^{\prime} 37^{\prime \prime} \mathrm{E}, 123 \mathrm{~m}$ a.s.1.; 26.X.2019; N. Ondrejková leg.; building interior; individual capture; 1 ㅇ, ILE SAS-1390 • Nitra; $48^{\circ} 18^{\prime} 43^{\prime \prime} \mathrm{N}$, 01805'18"E, 144 m a.s.1.; 12.II.2020; N. Král’ová leg.; building interior; individual capture; 1 ô, ILE SAS-1391 (Fig. 4C) • Same locality; 19.IV.2020; N. Králová leg.; building interior; individual capture; 1 q, ILE SAS-1392.

Observations. SLOVAKIA - Western Slovakia • Bratislava, Vrakuňa (Fig. 3); 48 $08^{\prime} 30^{\prime \prime} \mathrm{N}, 017^{\circ} 12^{\prime} 11^{\prime \prime} \mathrm{E}$, 132 m a.s.l.; 8.IX.2016; M. Everlingová; garden; photo

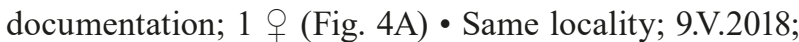
M. Everlingová; garden; photo documentation; 1 ㅇ (Fig. 4B) • Bratislava, Vajnory; $48^{\circ} 11^{\prime} 47^{\prime \prime} \mathrm{N}, 017^{\circ} 12^{\prime} 30^{\prime \prime} \mathrm{E}, 129$ $\mathrm{m}$ a.s.1.; 17.X.2019; S. Kuruc; building exterior; photo documentation; 1 (Fig. 5A) - Pezinok; 48 $17^{\prime} 13^{\prime \prime} \mathrm{N}$, $017^{\circ} 16^{\prime} 18^{\prime \prime} \mathrm{E}, 157 \mathrm{~m}$ a.s.1.; 25.XI.2019; M. Trojanová; building interior; photo documentation; 1 ઈิ (Fig. 5B).

Identification. Male pedipalp: embolus short, blunt with attendant membranous protrusion (Thaler and Knoflach 1998); median apophysis hook-shaped; cymbium with dorsal field of short, dense bristles; conductor transparent (Nentwig et al. 2020); tegulum proximally narrowed with sclerotized lateral sides (Thaler and Knoflach 1998) (Fig. 6). Female epigyne: scapus long, narrow, finger-shaped (Nentwig et al. 2020) (Fig. 7).

Measurements of Slovak specimens (Figs 4C, 6, 7). Male: body length: 15.51; prosoma length: 7.44, width 

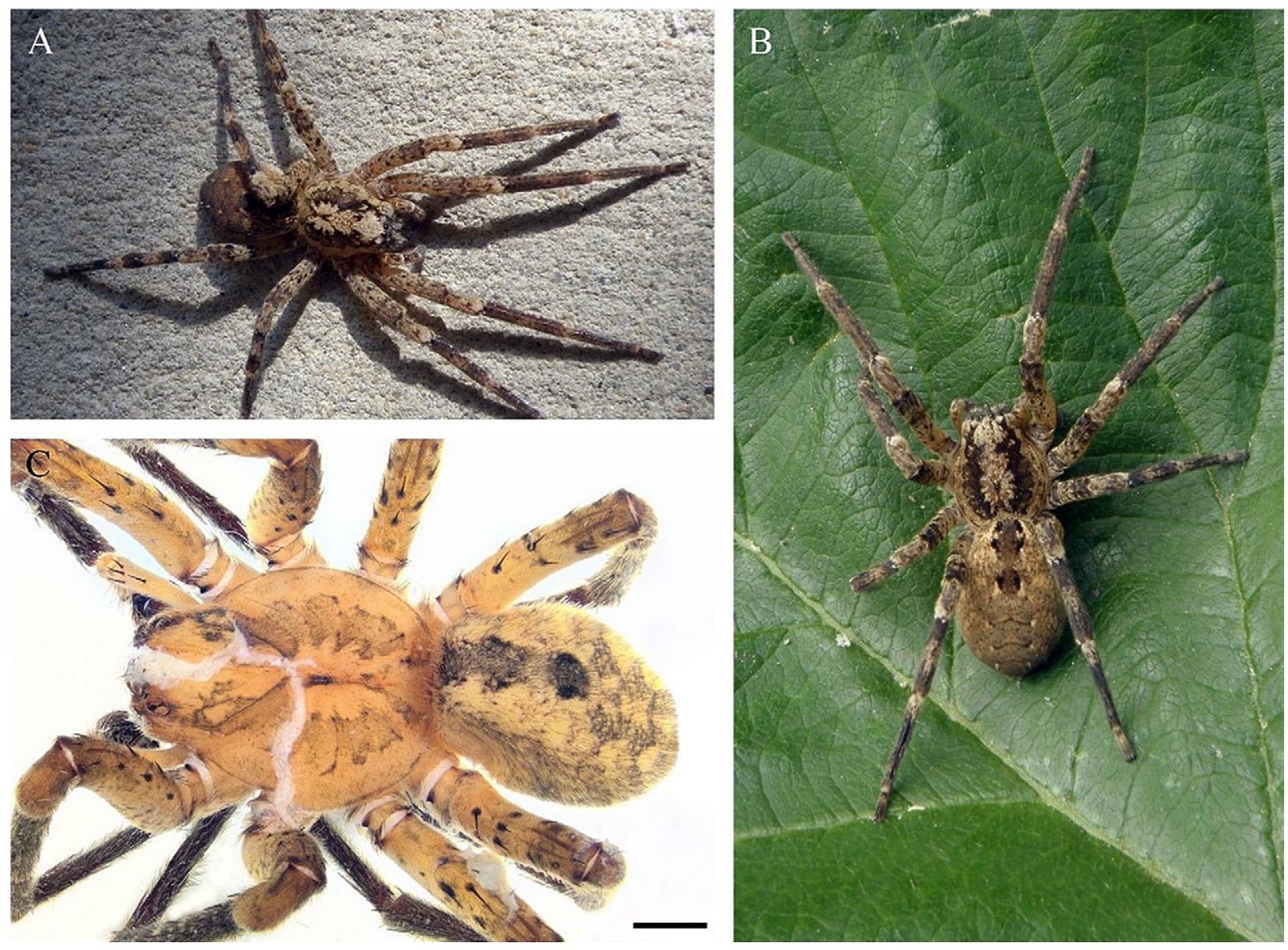

Figure 4. Zoropsis spinimana (Dufour, 1820) from Slovakia. A. First adult female from Bratislava, Vrakuňa (photo by M. Everlingová). B. Second adult female from Bratislava, Vrakuňa (photo by M. Everlingová). C. Adult male from Nitra. Scale bar $=2 \mathrm{~mm}$.
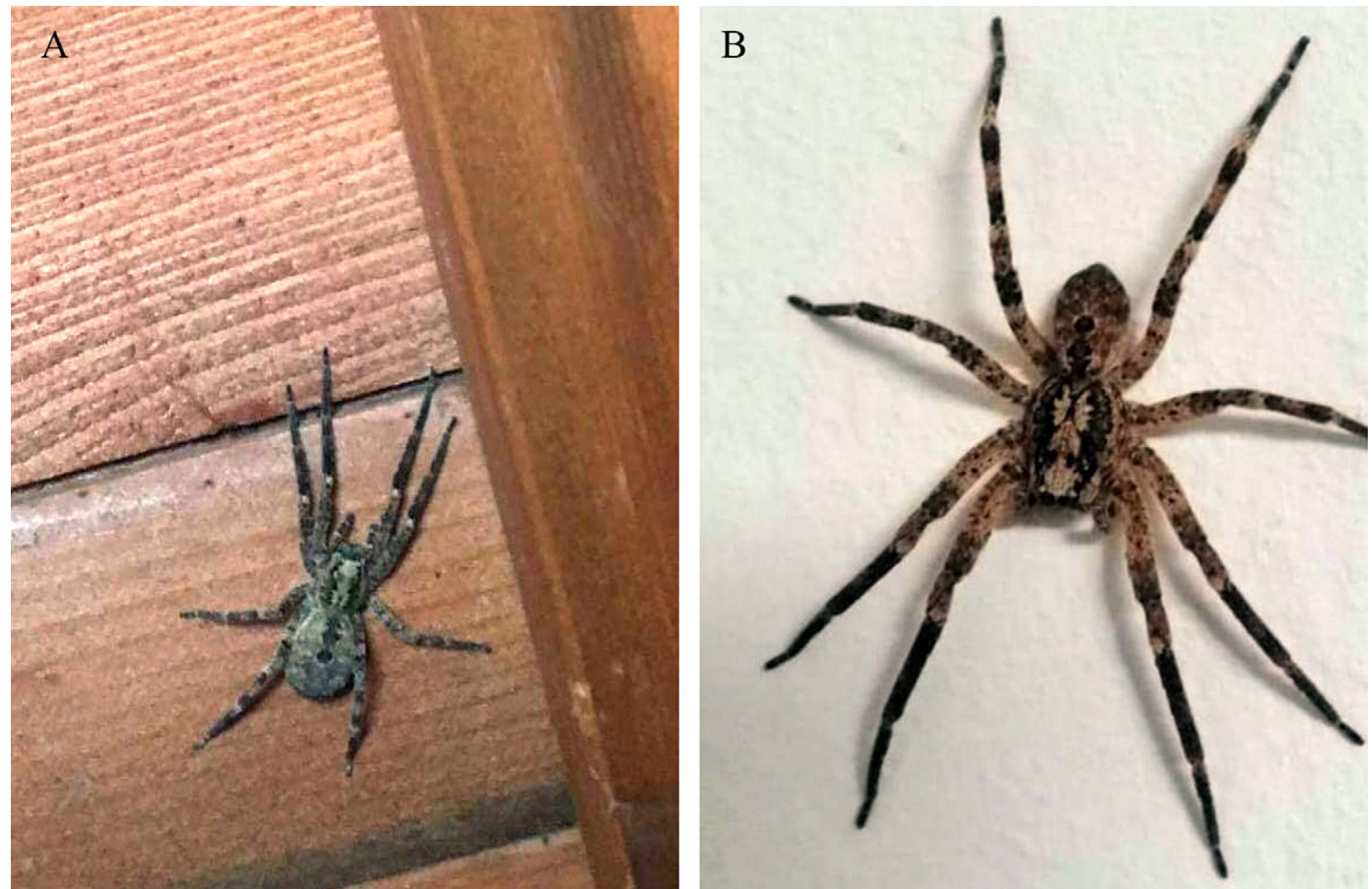

Figure 5. Zoropsis spinimana (Dufour, 1820) from Slovakia. A. Adult female from Bratislava, Vajnory (photo by S. Kuruc). B. Adult female from Pezinok (photo by M. Trojanová). 
A

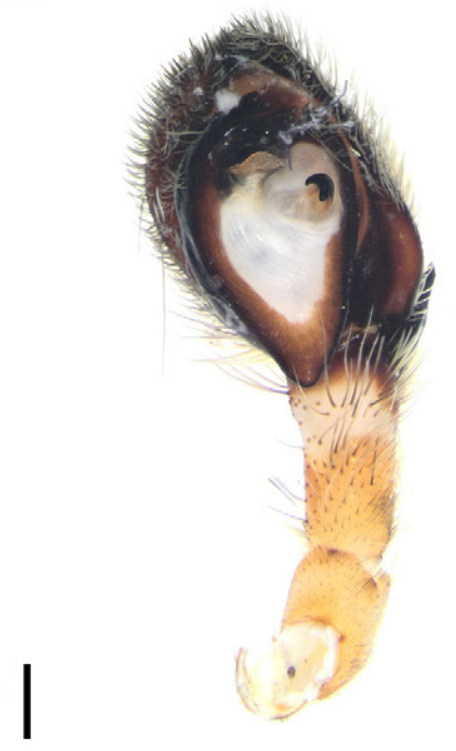

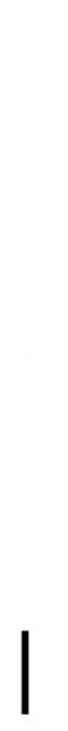

B

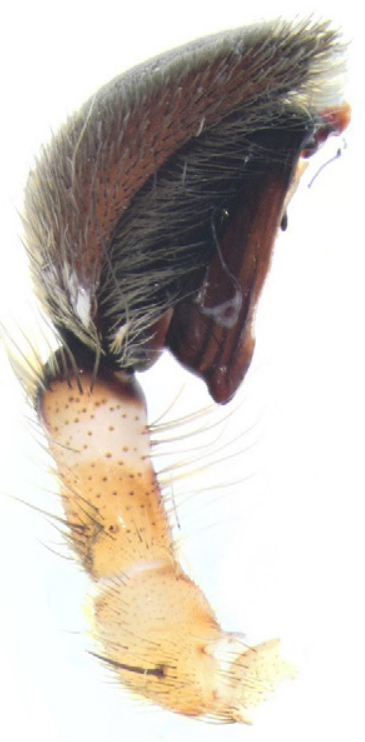

$\mathrm{C}$

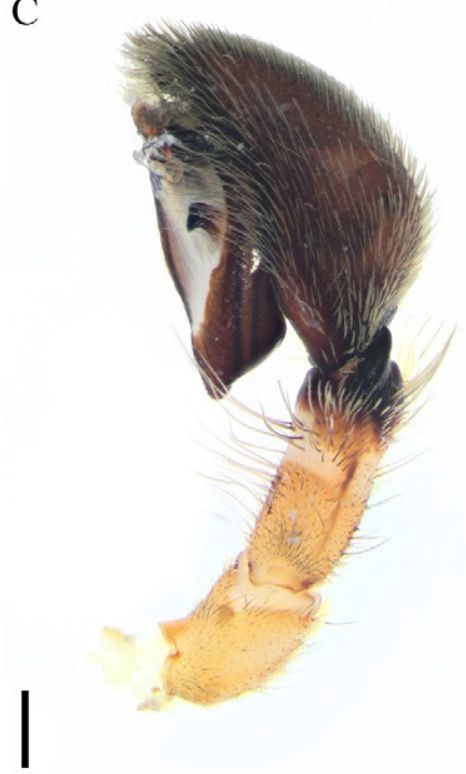

Figure 6. Zoropsis spinimana (Dufour, 1820), male from Slovakia. A. Left pedipalp, ventral view. B. Idem., prolateral view. C. Idem., retrolateral view. Scale bars $=0.5 \mathrm{~mm}$.

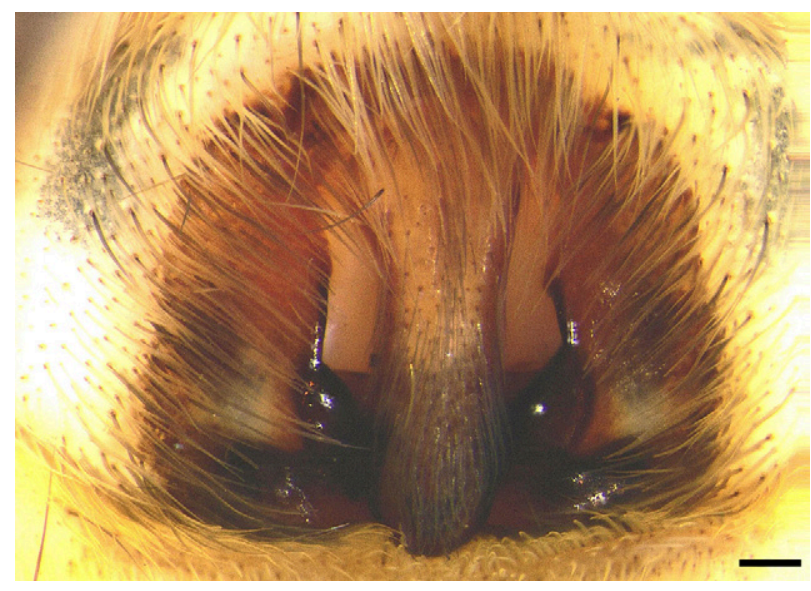

Figure 7. Zoropsis spinimana (Dufour, 1820), female from Slovakia, epigyne. Scale bar $=0.2 \mathrm{~mm}$.

6.65; opisthosoma length: 8.07, width 5.23. Females: body length: 13.23 and 16.28; prosoma length: 6.28 and 6.81, width 5.43 and 5.75; opisthosoma length: 6.95 and 9.44 , width 4.13 and 6.83 .

\section{Discussion}

The fast-running funnel-web spider T. hasperi has a distribution stretching from France to Turkey and southern European Russia (Nentwig et al. 2020; Fig. 1). In the Mediterranean, T. hasperi appears to inhabit habitats in direct sunlight, with tube-like silk retreats hidden under stones and wood or in crevices. In Bulgaria it was recorded under stones in open ground (Deltshev 1993); in Sicily, it has been collected from cracks in the rocks (Dentici 2019); in Hungary, it has been found under stones or wood, among tree roots in xerothermic forests, and inside the hollows of tree trunks (Kovács and Szinetár 2012); and in Turkey specimens were collected from the vicinity of a cave (Brignoli 1978) and under a stone (Seyyar et al. 2009). Furthermore, Kovács and Szinetár (2012) often found specimens of T. hasperi on the exterior walls of buildings (corners of the walls) in Hungary and Montenegro. Szinetár et al. (2020) emphasized the hemisynanthropic (moderately typical) nature of the occurrence of this species. The presence of T. hasperi is indeed often associated with human settlements or cultural landscapes. This species has been collected in vineyards in Switzerland (Hänggi et al. 2014), in an urban forest in the European part of Turkey (Demircan and Topçu 2016), on a green roof in Olympic Park, London, UK (Harvey 2015), and interiors of buildings in Hungary (Szinetár and Vajda 1992) and Switzerland (Hänggi and Straub 2016). Tegenaria hasperi was found only in one location in Slovakia. Our data suggest that this spider also inhabits other human-influenced habitats, specifically microhabitats in gardens. We assume that there are a sufficient number of microhabitats suitable for its occurrence in gardens, such as cavities under stones or tree roots. It is questionable whether the finding of two males represents a unique case of introduction or natural spread northwards from Hungary. Szinetár and Vajda (1992) assumed that synanthropic occurrence in Hungary is a way for this originally Mediterranean species to spread further north. Brignoli (1978) discussed the presence of $T$. hasperi in Turkey as a result of accidental passive transport with traded commodities from Italy in historical times. Future investigations are needed to determine if $T$. hasperi occurs exclusively in gardens or also inhabits more natural habitats in Slovakia.

In Europe and the Caucasus, Spiny False Wolf Spider, Z. spinimana, is distributed from the Mediterranean to the European part of Russia and Georgia (Nentwig et al. 2020; Fig. 3). In 1992, this species was found to 
be introduced into the USA (Griswold and Ubick 2001). Since the mid-1990s, Z. spinimana spread to the northern parts of Europe, with the first published records coming from Austria (Thaler and Knoflach 1998) and Switzerland (Hänggi 2003). More recently, Z. spinimana recorded in Germany (Hänggi and Bolzern 2006), Belgium (Lambeets et al. 2007), the Netherlands (van Helsdingen 2007), Hungary (Szinetár et al. 2014), Luxemburg (Massard and Geimer 2018; Kreuels et al. 2019), and the Czech Republic (Dolejš and Prudek 2019). Outside continental Europe, the species is known to occur in the United Kingdom (Harvey 2012) and the Azores (Borges et al. 2013). Zoropsis spinimana originated from the Mediterranean (Thaler and Knoflach 1998), where it lives under bark and stones in open forests, but it also often occurs synanthropically in buildings and on their facades (Nentwig et al. 2020). In Central Europe, its occurrence is mostly eusynanthropic (Szinetár et al. 2020), being found in the interiors of buildings, and sporadically in the vicinity of human dwellings as well (Hänggi and Bolzern 2006; Kreuels 2007a; Lambeets et al. 2007). Hänggi (2020) described finding it in birdhouses, which show that this species can in some cases be found outside of human dwellings. The previous record closest to our findings was from a car service station in Brno (Czech Republic), but $Z$. spinimana is not yet considered established in the Czech fauna (Dolejš and Prudek 2019). The rail and road traffic concentrated along the Rhine, together with the favourable climatic conditions there, may be of importance for the spread of this species in Germany (Nedvěd et al. 2011). In Slovakia as well, Z. spinimana was recorded exclusively from synanthropic habitats in four cities of the western region (Bratislava, Nitra, Pezinok, and Sered'). While the finding in the warehouse of the logistics centre in Sered' could be an accidental occurrence, because there is a possibility of transporting spiders with wares, other findings come from the exterior or interior of buildings, suggesting that $Z$. spinimana has been able to create permanent populations in Slovakia. As in neighboring countries, the new records of $Z$. spinimana in Slovakia are all from the Pannonian basin (Fig. 3). It seems likely that the warm climatic conditions of western Slovakia are allowing for this species' spread from Hungary and Austria, where it was earlier recorded (Thaler and Knoflach 1998; Szinetár et al. 2014). Given its occurrence in neighboring countries (Hungary, Austria, Czech Republic), the occurrence of this species in Slovakia is not very surprising. It is very likely that this species will continue to spread across Europe and that findings will increase. Zoropsis spinimana is a large and conspicuous spider, often observed by the general public, and can be determined using photographs, as were used by us and in other surveys (Harvey 2012; Atlas of European Arachnids 2021; Spider and Harvestman Recording Scheme website 2021). Although this spider is not a medically important species for humans, several observations have shown that $Z$. spinimana is capable of causing painful bites (Emerit and Bonaric 1995; Kreuels 2007b;
Nentwig et al. 2013; Bertlich et al. 2018). It is likely that bites of Z. spinimana will be reported from Slovakia in connection with its spread, as its synanthropic potential may cause frequent interactions with humans.

\section{Acknowledgements}

The study was partially supported by the Slovak Grant Agency of the Ministry of Education, Science, Research and Sport of the Slovak Republic, as part of projects VEGA No. 2/0078/18 (Research of biocultural values of landscape), No. 1/0604/20 (Environmental assessment of specific habitats of the Danubian Lowland), and UGA VIII/16/2020 (Evaluation of the Biodiversity and its Conservation Strategy in the High Valuable Areas of the Landscape Created and used by Man on the Model Spider Group). We are grateful to James Asher and Mathew Sebastian who improved the English of the manuscript and to the reviewers for their constructive comments.

\section{Authors' Contributions}

PP identified Z. spinimana individuals, measured and photographed individuals and wrote the manuscript. NO and ZK collected and identified specimens T. hasperi and revised the text. NH created maps. PG identified some individuals of $Z$. spinimana and revised the text.

\section{References}

Atlas of European Arachnids, SW Version 1.102.2 (2021) Arachnologische Gesellschaft. https://atlas.arages.de/species/825. Accessed on: 2021-4-8.

Bertlich I, Enk A, Haenssle HA, Hofer H, Haus G (2018) Extensive local reaction after bite of the Mediterranean spider Zoropsis spinimana. Journal der Deutschen Dermatologischen Gesellschaft 17 (1):76-78.

Bílek P (1975) Arachnofauna východní časti Polabské nížiny a dva nové druhy pavouků pro ČSSR. Z minulosti a prítomnosti Turca (Martin) 3: 111-118.

Borges PAV, Reut M, Ponte NB, Quartau JA, Fletcher M, Sousa AB, Pollet M, Soares AO, Marcelino J, Rego C, Cardoso P (2013) New records of exotic spiders and insects to the Azores, and new data on recently introduced species. Arquipelago - Life and Marine Sciences 30: 57-70.

Brignoli PM (1978) Ragni di Turchia V. Specie nuove o interessanti, cavernicole ed epigee, di varie famiglie (Araneae). Revue Suisse de Zoologie 85 (3): 461-541. https://doi.org/10.5962/bhl.part.82243

Deltshev C (1993) The genus Tegenaria Latreille in Bulgaria: a critical review with descriptions of two sibling species (Arachnida, Araneae: Agelenidae). Berichte des Naturwissenschaftlich-Medizinischen Vereins in Innsbruck 80: 167-174.

Demircan N, Topçu A (2016) First records for spider fauna of the European part of Turkey (Araneae). Serket 15: 85-91.

Dentici A (2019) Third contribution to the knowledge of Sicilian spider fauna (Arachnida Araneae). Biodiversity Journal 10 (2): 117120. https://doi.org/10.31396/Biodiv.Jour.2019.10.2.117.120

Dolejš P, Prudek M (2019) Zoropsis spinimana in the Czech Republic? Pavouk 46: 5.

Emerit M, Bonaric JC (1995) Un cas d'envenimation de type loxoscélique attribué a l'araignée Zoropsis spinimana dans le midi de la France. Annales de la Société d'Horticulture et d'Histoire Naturelle de l'Hérault 135: 37-38. 
Griswold CE, Ubick D (2001) Zoropsidae: a spider family newly introduced in the USA (Araneae, Entelegynae, Lycosoidea). Journal of Arachnology 29: 111-113. https://doi.org/10.1636/01618202(2001)029[0111:zasfni]2.0.co;2

Harvey PR (2012) Zoropsis spinimana (Dufour, 1820) established indoors in Britain. Newsletter of the British Arachnological Society $125: 20-21$.

Harvey PR (2015) Spider Recording Scheme News No. 82. Newsletter of the British Arachnological Society 133: 17.

Hänggi A (2003) Nachträge zum 'Katalog der schweizerischen Spinnen' 3. Neunachweisevon 1999 bis 2002 und Nachweise synanthroper Spinnen. Arachnologische Mitteilungen 26: 36-54. https:// doi.org/10.5431/aramit2604

Hänggi A, Bolzern A (2006) Zoropsis spinimana (Araneae: Zoropsidae) neu für Deutschland. Arachnologische Mitteilungen 32: 8-10. https://doi.org/10.5431/aramit3202

Hänggi A, Straub S (2016) Storage buildings and greenhouses as stepping stones for non-native, potentially invasive spiders (Araneae)a baseline study in Basel, Switzerland. Arachnologische Mitteilungen 51: 1-8. https://doi.org/10.5431/aramit5101

Hänggi A, Inches S, Brunner S (2020) Zoropsis spinimana-eine gebietsfremde Spinnenart aus dem Mittelmeerraum besiedelt auch Vogelnistkästen. Ornithologischer Beobachter 117: 262-266.

Hänggi A, Stäubli A, Heer X, Trivellone V, Paltrinieri LP, Moretti M (2014) Eleven new spider species (Arachnida: Araneae) for Switzerland discovered in vineyards in Ticino-What are possible reasons? Mitteilungen der Schweizerischen Entomologischen Gesellschaft 87: 215-228.

Helsdingen van PJ (2007) From the outer front. Nieuwsbrief SPINED (Nieuwsbrief van de Spinnenwerkgroep Nederland) 23: 36.

Ištok R (1999) Regionálny štát a jeho politickogeografická interpretácia. In: Acta facultatis studiorum humanitatis et naturae Universitatis Prešoviensis. Prírodné vedy. Folia Geographica 3. Zborník štúdií z XII. Zjazdu SGS. Prešov, Fakulta humanitných a prírodných vied Prešovská univerzita v Prešove, Slovakia 139-144. In: Djurbová A (2020) Niekol'ko poznámok k Slovensku ako politickému regiónu. Acta Geographica Universitatis Comenianae 64.1: 91-122.

Kostanjšek R, Kuntner M (2002) Poročilo o delu araneološke skupine. In: Govedič M (Ed.) Raziskovalni tabor študentov biologije Šempas '98. Zveza za tehnično kulturo Slovenije, Gibanje znanost mladini \& Društvo študentov biologije, Ljubljana, 23-25.

Kovács G, Szinetár Cs (2012) Adatok az ezüstös zugpók (Malthonica nemorosa [Simon, 1916]) biológiájához (Araneae, Agelenidae). A nyme Savaria egyetemi Központ tudományos Közleményei XiX. Természettudományok 14: 151-164.

Kreuels M (2007a) Die Kräuseljagdspinne Zoropsis spinimana. Pest Control 36: 16 .

Kreuels M (2007b) Zoropsis spinimana (DUFOUR, 1820) ein weiterer Wanderer von Süden nach Norden. Natur und Heimat 67: 32.

Kreuels M, Staudt A, Christian S (2019) Die Spinnenfauna von Luxemburg - eine Zusammenstellung der Nachweise aus den Jahren 1906-2018 (Arachnida: Araneae). Bulletin de la Société des Naturalistes Luxembourgeois 121: 203-230

Kuntner M, Kostanjsek R (2000) Prispevek k poznavanju favne pajkov zahodne Slovenije (Arachnida: Araneae). Natura Sloveniae 2: $13-28$.

Lambeets K, Bosmans R, Bonte D (2007) Two exotic spider species (Araneae), Zoropsis spinimana (Zoropsidae) and Saitis barbipes (Salticidae), recently found in the inner city of Ghent (Belgium). Nieuwsbrief van de Belgiche Arachnologische Vereniging 22: 55-60.
Massard JA, Geimer G (2018) Kräuseljagdspinne in Echternach entdeckt-Keine Gefahr für den Menschen. Lëtzebuerger Journal 268: 18.

Miller F, Žitňanská O (1976) Einige bemerkenswerte Spinnen aus der Slowakei. Biológia (Bratislava) 31 (2): 81-89.

Nedvěd O, Pekár S, Bezděčka P, Líznarová E, Řezáč M, Schmitt M, Sentenská L (2011) Ecology of Arachnida alien to Europe. BioControl 56: 539-550. https://doi.org/10.1007/s10526-011-9385-3

Nentwig W, Gnädinger M, Fuchs J, Ceschi A (2013) A two year study of verified spider bites in Switzerland and a review of the European spider bite literature. Toxicon 73: 104-110. https://doi. org/10.1016/j.toxicon.2013.07.010

Nentwig W, Blick T, Gloor D, Hänggi A, Kropf C (2020) Araneae Spiders of Europe, version 07.2020 http://www.araneae.nmbe.ch. Accessed on 2020-3-15. https://doi.org/10.24436/1

Seyyar O, Demir H, Topçu A (2009) A further faunistic study on two species of the genus Malthonica Simon, 1898 (Araneae: Agelenidae) from Turkey. Turkish Journal of Arachnology 1 (2): 120-127.

Spider and Harvestman Recording Scheme website (2021) The national recording schemes for spiders and harvestmen in Britain. British Arachnological Society. http://srs.britishspiders.org.uk/ portal.php/p/Zoropsis + spinimana + established + indoors $+\mathrm{in}+$ Brit ain. Accessed on: 2021-4-8.

Suvák M (2013) Invasive spider Uloborus plumipes Lucas, 1846 (Araneae: Uloboridae), new to Slovakia. Folia faunistica Slovaca 18: 39-45.

Szinetár C, Vajda Z (1992) The occurrence of a rare South European spider species, Tegenaria nemorosa Simon, 1916, in Hungary (Araneidea). Folia Entomologica Hungarica 53: 257-258.

Szinetár C, Török T, Szüts T (2014) Zoropsis spinimana, mint új épületlakó pókfaj magyarországon. A Nyme Savaria Egyetemi Központ Tudományos Közleményei XX. Természettudományok 15: 105-113.

Szinetár C, Kovács G, Urák I, Gajdoš P (2020) Synanthrophic spider fauna of the Carpathian Basin in the last three decades. Biologia Futura 71: 31-38. https://doi.org/10.1007/s42977-020-00009-5

Šestáková A, Gajdoš P (2011) Expanzný druh snovačky Parasteatoda tabulata Levi, 1980 (Araneae, Theridiidae) na Slovensku. Folia faunistica Slovaca 16: 169-172.

Šestáková A, Christophoryová J, Korenko S (2013) A tropical invader, Coleosoma floridanum, spotted for the first time in Slovakia and the Czech Republic (Araneae, Theridiidae). Arachnologische Mitteilungen 45: 40-44. https://doi.org/10.5431/aramit4509

Šestáková A, Černecká L', Gajdoš P (2017) Cudzie druhy (nielen) v záhradných centrách. Abstract book XVth Arachnological conference, SARAS 15: 30.

Šestáková A, Černecká L', Neumann J, Reiser N (2014) First record of the exotic spitting spider Scytodes fusca (Araneae, Scytodidae) in Central Europe from Germany and Slovakia. Arachnologische Mitteilungen 47: 1-6. https://doi.org/10.5431/aramit4701

Thaler K, Knoflach B (1998) Zoropsis spinimana (Dufour), eine für Österreich neue Adventivart (Araneae, Zoropsidae). Berichte des naturwissenschaftlichen-medizinischen Verein Innsbruck 85: 173-185.

World Spider Catalog, version 22.0 (2021) Natural History Museum Bern. https://wsc.nmbe.ch/. Accessed on: 2021-4-14. https://doi. org $/ 10.24436 / 2$

Žitňanská O (1975) Doterajšie výsledky arachnologického výskumu na Zoologickom ústave Prírodovedeckej fakulty UK v Bratislave. Z minulosti a prítomnosti Turca (Martin) 3: 119-125. 